\title{
HISTOPATHOLOGICAL ANALYSIS OF CHRONIC GASTRITIS AND CORRELATION OF PATHOLOGICAL FEATURES WITH EACH OTHER AND WITH ENDOSCOPIC FINDINGS
}

\author{
Bhavna Garg ${ }^{1}$, Vineet Sandhu ${ }^{2}$, Neena Sood ${ }^{1}$, Ajit Sood ${ }^{1}$, Vineeta Malhotra ${ }^{1}$
}

1Dayanand Medical College \& Hospital, Ludhiana, India

2PGIMER, Chandigarh, India

\begin{abstract}
Chronic gastritis is a very common disorder which is commonly caused by Helicobacter pylori. Histopathological examination is the mainstay of the diagnosis. We evaluated 300 gastric antral biopsies using revised Sydney system and concluded that it helps to analyse gastric biopsies in a very comprehensive manner. It was seen that $H$. pylori, chronic inflammatory infiltrate, neutrophilic infiltration, presence of lymphoid follicles and aggregates and surface epithelial damage are strongly associated with each other. The presence of one of these histological feature is a strong indicator for presence of other features. On the other hand intestinal metaplasia and atrophy of gastric glands was not associated with the above mentioned histological features. In the presence of dense chronic inflammation and infiltration by neutrophils one should carefully search for $H$. pylori organism. We also correlated histological features with endoscopy and found that cases of duodenal ulcer had more severe antral gastritis on histology as compared to those with hyperemia or antral erosions.
\end{abstract}

Key words: Helicobacter pylori, gastritis, inflammation.

\section{Introduction}

Gastritis, perhaps best defined as the inflammatory response of the gastric mucosa to injury, is an extremely common condition worldwide. The fundamental histologic change is an increase in the inflammatory cells in the gastric mucosa. Acute gastritis refers to acute mucosal damage after acute alcohol intoxication, drugs, corrosive substance, gastric irradiation etc. Chronic gastritis is mainly characterized by two main features, i.e. infiltration of lamina propria by chronic inflammatory cells and glandular atrophy. For the past 20 years the increased use of endoscopy with biopsy has revolutionized our understanding of the nature and significance of chronic gastritis. Chronic infection with $\mathrm{He}$ licobacter pylori is now believed to account for the majority of cases of chronic gastritis. It is also linked to acute gastritis, dyspepsia, peptic ulcer, gastric adenocarcinoma and gastric non-Hodgkin's lymphoma of mucosa-associated lymphoid tissue (MALT).

In spite of numerous flaws, histopathological examination remains the gold standard for diagnosis. Helicobacter pylori is a curved to wavy bacterium, which can be identified by hematoxylin and eosin stain when numerous, but is more reliably recognized by other histochemical stains like Giemsa, Warthin-Starry or silver stains. The pattern of inflammation is usually characterized by a mixed acute and chronic inflammatory cell infiltrate in the lamina propria frequently accompanied by intraepithelial infiltration of neutrophils. As there is an effective specific treatment for $H$. pyloriassociated gastroduodenal disorders, pathologists are usually requested to identify the organism in endoscopic biopsies.

In 1990, the Sydney system [1] for grading and classifying chronic gastritis was devised to provide a stan- 
dardized approach to interpretation of antral biopsies. It emphasizes the importance of combining topographical, morphological and etiological information which would help to generate reproducible and clinically useful diagnosis. This system was reappraised and upgraded in 1994 in a workshop in Houston, Texas [2]. The aims of this workshop were to establish an agreeable terminology of gastritis and to resolve problems of the Sydney system. This system was based on both endoscopic and histologic findings. This system classified gastritis as acute gastritis, chronic gastritis and a special form of gastritis. Since the Sydney system provides a relatively subjective score, in 2002, a modification with a more objective score was proposed by Aydin et al. [3]. This technique was more simple and a rapid evaluation of the biopsy was done. Since density of $H$. pylori and the different inflammatory factors appear related to each other, it should be possible to predict presence or absence of one inflammatory parameter based on the presence or absence of a different factor which would also enable the pathologist to give the clinician an overall grade of severity of gastritis.

This study was designed with the following aim: (i) to evaluate histopathological parameters of chronic gastritis according to the revised Sydney system by Aydin et al. [3], (ii) to correlate histopathological parameters with endoscopic findings, and (iii) to study the relationship between various histological parameters.

\section{Material and methods}

The present study is a one and a half years' prospective study (from January 2008 to June 2009), in which all endoscopic antral biopsies received in the department of Pathology, Dayanand Medical College \& Hospital, Ludhiana (India) were analysed with reference to light microscopic findings.

Inclusion criteria for the study were as follows: all patients presenting with chronic ulcer as well as nonulcer dyspepsia. Exclusion criteria included patients with a present or past history of either gastric neoplasms, gastric surgery or long-term therapy with nonsteroidal anti-inflammatory drugs, etc. All subjects had given informed consent to study inclusion and a local ethics committee had approved the protocol. Endoscopy was performed and findings, i.e. hyperemia, erosions, ulcerations etc. were recorded and endoscopic biopsies were taken. These were immediately fixed in formalin for histopathological examination.

All biopsies were oriented and processed by routine techniques. 3-4 micrometer thick sections were cut from each block and were stained using hematoxylin and eosin stain. Giemsa stain was done on all biopsies to identify the $H$. pylori organism. The slides were evaluated by two pathologists and a score of 0 to 3 (absent, mild, moderate, marked) was assigned to each morphological variable. Helicobacter pylori density, density

Table I. Grading criteria of gastric biopsies according to revised Sydney System by Aydin et al. [3]

\begin{tabular}{|c|c|c|}
\hline TYPE OF FEATURE & DENSITY OF THE HISTOLOGICAL FEATURE & GRADE \\
\hline \multirow{4}{*}{$\begin{array}{l}\text { chronic inflammation } \\
\text { (lymphocytes } \\
\text { and plasma cells) }\end{array}$} & 2-3 chronic inflammatory cells scattered randomly in the biopsy & nil (0) \\
\hline & 10-15 chronic inflammatory cells/hpf & mild (1) \\
\hline & some areas with dense chronic inflammatory cells & moderate (2) \\
\hline & diffuse infiltration with dense chronic inflammatory cells & marked (3) \\
\hline \multirow{4}{*}{$\begin{array}{l}\text { neutrophilic } \\
\text { infiltration }\end{array}$} & no neutrophils anywhere in the biopsy & nil (0) \\
\hline & scattered neutrophils in the biopsy & mild (1) \\
\hline & $\begin{array}{l}\text { foci of dense neutrophilic infiltrate with scattered neutrophils } \\
\text { in the rest of the biopsy }\end{array}$ & moderate (2) \\
\hline & $\begin{array}{l}\text { several foci of dense inflammatory infiltrate in the biopsy } \\
\text { with involvement of crypts }\end{array}$ & marked (3) \\
\hline \multirow[t]{4}{*}{ atrophy } & no evidence of gastric gland loss & nil $(0)$ \\
\hline & small areas where gastric glands have disappeared $(<25 \%)$ & mild (1) \\
\hline & $25-50 \%$ of the biopsy shows loss of gastric glands & moderate (2) \\
\hline & $>50 \%$ of the biopsy shows loss of gastric glands & marked (3) \\
\hline \multirow[t]{4}{*}{ intestinal metaplasia } & no intestinal metaplasia & nil $(0)$ \\
\hline & focal areas of intestinal metaplasia (1-4 crytps) & mild (1) \\
\hline & multiple foci involving $>4$ crypts but $<50 \%$ of the biopsy & moderate $(2)$ \\
\hline & intestinal metaplasia involving $>50 \%$ of the biopsy specimen & marked (3) \\
\hline \multirow[t]{4}{*}{ H. pylori density } & no $H$. pylori anywhere in the biopsy & nil (0) \\
\hline & only a few $H$. pylori seen in single or multiple foci & mild (1) \\
\hline & numerous $H$. pylori seen in separate areas of foci & moderate (2) \\
\hline & $>50 \%$ of the surface area covered with $H$. pylori & marked (3) \\
\hline
\end{tabular}


Table II. Histological scoring index as proposed by Wootherspoon et al. [4]

\begin{tabular}{lll}
\hline GRADE & DESCRIPTION & HISTOLOGICAL FEATURES \\
\hline 0 & normal & scattered plasma cells in lamina propria, no lymphoid follicles \\
\hline 1 & chronic active gastritis & $\begin{array}{l}\text { small clusters of lymphocytes in lamina propria, no lymphoid } \\
\text { follicles, no LELs }\end{array}$ \\
\hline 2 & $\begin{array}{l}\text { chronic active gastritis with florid } \\
\text { lymphoid follicles formation }\end{array}$ & $\begin{array}{l}\text { prominent lymphoid follicles with surrounding mantle zone } \\
\text { and plasma cells no LELs }\end{array}$ \\
\hline 3 & $\begin{array}{l}\text { suspicious lymphoid infiltrate } \\
\text { in lamina propria, probably reactive }\end{array}$ & $\begin{array}{l}\text { lymphoid follicles surrounded by small lymphocytes that } \\
\text { infiltrates diffusely in lamina propria and occasionally } \\
\text { into epithelium }\end{array}$ \\
\hline 4 & $\begin{array}{l}\text { suspicious lymphoid infiltrate } \\
\text { in lamina propria, probably lymphoma }\end{array}$ & $\begin{array}{l}\text { lymphoid follicles surrounded by CCL cells that infiltrate } \\
\text { diffusely in lamina }\end{array}$ \\
\hline 5 & low grade B-cell lymphoma of MALT & $\begin{array}{l}\text { presence of dense diffuse in filtrate of CCL cells in lamina } \\
\text { propria with prominent LELs }\end{array}$ \\
\hline
\end{tabular}

LEL - lymphoepithelial lesion, CCL - centrocyte like lesion

Table III. Age wise distribution of chronic gastritis

\begin{tabular}{ccc}
\hline Age group & Total No. Of CASES & PercentaGe \\
\hline$<15$ & 3 & $1 \%$ \\
\hline $16-30$ & 64 & $21.33 \%$ \\
\hline $31-45$ & 73 & $24.33 \%$ \\
\hline $46-60$ & 94 & $31.33 \%$ \\
\hline $61-75$ & 55 & $18.33 \%$ \\
\hline$>75$ & 11 & $3.67 \%$ \\
\hline
\end{tabular}

of neutrophils, lymphocytes and plasma cells were recorded. Glandular atrophy and intestinal metaplasia were also noted and graded according to the above three categories. The grading of presence of lymphoid follicles was done per histologic scoring index as proposed by Wotherspoon et al. [4].

For each variable, the highest score was given among antral biopsies according to the scoring system used by Aydin et al. [3] (Table I). Grading of lymphoid follicles was done by the index proposed by Wotherspoon et al. [4] (Table II).

\section{Statistical analysis}

The association between histological findings was assessed by means of $\chi^{2}$ test for trend [5]. A probability value of $p=0.05$ was considered statistically significant.

\section{Results}

In the present study, 400 endoscopic antral biopsies were received in our department between January 2008 and June 2009; out of which 100 patients had either a history of gastric neoplasm, surgery or long treatment by NSAIDS. So, these 100 patients were ex-
Table IV. Endoscopic findings in all the patients

\begin{tabular}{lcc}
\hline ENDOSCOPIC FINDINGS & NO. OF CASES & $\%$ AGE \\
\hline antral hyperemia & 204 & 68 \\
\hline antral erosion & 21 & 7 \\
\hline duodenal ulcer & 15 & 5 \\
\hline normal gastric mucosa & 60 & 20 \\
\hline $\begin{array}{l}\text { Hypermia was most commonly encountered endoscopically. } \\
\text { Histological features in all 300 biopsies in accordance with revised Sydney } \\
\text { classification. }\end{array}$
\end{tabular}

cluded from the study. Hence, 300 antral biopsies were analysed taking into consideration the endoscopic findings and various histological parameters such as chronic inflammatory infiltrate, inflammatory activity, glandular atrophy, intestinal metaplasia, surface epithelial damage, $H$. pylori and intestinal metaplasia.

Number of endoscopic antral biopsies analysed $=300$

Most common age group affected by chronic gastritis was 46-60 years (Table III). There were 204 males and 96 females with an $\mathrm{M}: \mathrm{F}$ ratio of $2.1: 1$.

\section{The endoscopic findings}

Chronic inflammatory activity was seen maximally in duodenal ulcer (60\%), followed by antral erosions and then hyperemia. In $22 \%$ of cases having a normal looking mucosa on endoscopy, inflammatory activity was seen. Histologically $H$. pylori density and lymphoid follicles was maximum in duodenal ulcer. In most cases, glandular atrophy was noted in endoscopically normal looking mucosa, while intestinal metaplasia was maximally seen in cases having antral hyperemia. 
Table V. Histological grading of all biopsies according to revised Sydney system [3]

\begin{tabular}{|c|c|c|}
\hline HISTOLOGICAL FEATURES & GRADE & $\begin{array}{l}\text { NUMBER } \\
\text { OF CASES }\end{array}$ \\
\hline \multirow[t]{4}{*}{ chronic inflammation } & nil & $0(0 \%)$ \\
\hline & mild & $210(70 \%)$ \\
\hline & moderate & $82(27.33 \%)$ \\
\hline & marked & $8(2.6 \%)$ \\
\hline \multirow{4}{*}{$\begin{array}{l}\text { neutrophilic infiltration } \\
\text { (activity) }\end{array}$} & nil & $200(66.67 \%)$ \\
\hline & mild & $63(2 \%)$ \\
\hline & moderate & $35(11.67 \%)$ \\
\hline & marked & $2(0.67 \%)$ \\
\hline \multirow[t]{4}{*}{ glandular atrophy } & nil & $263(87.67 \%)$ \\
\hline & mild & $30(10.00 \%)$ \\
\hline & moderate & $7(2.33 \%)$ \\
\hline & marked & $0(0.00 \%)$ \\
\hline \multirow[t]{4}{*}{ intestinal metaplasia } & nil & $279(93 \%)$ \\
\hline & mild & $16(5.33 \%)$ \\
\hline & moderate & $5(1.67 \%)$ \\
\hline & marked & $0(0.00 \%)$ \\
\hline \multirow[t]{4}{*}{ density of $H$. pylori } & nil & $169(56.33 \%)$ \\
\hline & mild & $121(40.33 \%)$ \\
\hline & moderate & $10(3.33 \%)$ \\
\hline & marked & $0(0.00 \%)$ \\
\hline \multirow{4}{*}{$\begin{array}{l}\text { surface epithelial } \\
\text { damage }\end{array}$} & nil & $4(1.33 \%)$ \\
\hline & mild & $258(86.00 \%)$ \\
\hline & moderate & $3(1.00 \%)$ \\
\hline & marked & $35(11.67 \%)$ \\
\hline
\end{tabular}

\section{Intercorrelation among various histological parameters}

A. Correlation of chronic inflammatory infiltrate with other histological parameters

The density of chronic infiltrate was strongly associated with the presence of inflammatory infiltrate
Table VI. Distribution of cases on basis of grade of lymphoid follicles as per the histological scoring index proposed by Wootherspoon et al. [4]

\begin{tabular}{lc}
\hline Grade & Number OF CASES WITH \% AGE \\
\hline 0 & $163(54.33 \%)$ \\
\hline 1 & $76(25.33 \%)$ \\
\hline 2 & $59(19.66 \%)$ \\
\hline 3 & $0(0.00 \%)$ \\
\hline 5 & $0(0.00 \%)$ \\
\hline
\end{tabular}

$(\mathrm{p}=0.00)$; density of H. pylori $(\mathrm{p}=0.00)$, surface epithelial damage $(\mathrm{p}=0.01)$ and lymphoid follicles $(\mathrm{p}=0.00)$. No significant association of chronic inflammatory infiltrates with glandular atrophy $(\mathrm{p}=0.10)$ and intestinal metaplasia $(\mathrm{p}=0.15)$ was observed.

B. Inflammatory activity and its correlation with other histological parameters

A statistically significant relation between inflammatory activity and density of $H$. pylori $(\mathrm{p}=0.00)$; surface epithelial damage $(\mathrm{p}=0.02)$ and lymphoid follicles ( $p=0.00)$ was observed. There was no significant association between inflammatory infiltrate and glandular atrophy $(\mathrm{p}=0.58)$ along with intestinal metaplasia $(\mathrm{p}=0.99)$.

C. Correlation of $H$. pylori with various other histological parameters

There was a very strong association between chronic inflammatory infiltrates, activity, surface epithelial damage and lymphoid follicles; while glandular atrophy and intestinal metaplasia showed no correlation.

D. Correlation of glandular atrophy with other histological parameters

There was a statistically significant correlation between glandular atrophy and intestinal metaplasia; while there was no correlation with chronic infiltrate,

Table VII. Endoscopic and histological correlation

\begin{tabular}{|c|c|c|c|c|}
\hline $\begin{array}{l}\text { HISTOLOGICAL } \\
\text { FEATURES }\end{array}$ & $\begin{array}{l}\text { ANTRAL HYPEREMIA } \\
(\text { TOTAL CASES }=204)\end{array}$ & $\begin{array}{c}\text { ANTRAL EROSION } \\
(\text { TOTAL CASES }=21)\end{array}$ & $\begin{array}{l}\text { DUODENAL ULCERS } \\
(\text { TOTAL CASES }=15)\end{array}$ & $\begin{array}{c}\text { NORMAL } \\
(\text { TOTAL CASES }=60)\end{array}$ \\
\hline \multirow{3}{*}{$\begin{array}{l}\text { chronic inflammatory } \\
\text { infiltrate }\end{array}$} & mild - 145 & mild - 11 & mild -4 & mild - 50 \\
\hline & moderate -51 & moderate -10 & moderate -11 & moderate -10 \\
\hline & severe -8 & severe -0 & severe -0 & severe -0 \\
\hline activity & $66(32 \%)$ & $12(57 \%)$ & $9(60 \%)$ & $13(22 \%)$ \\
\hline surface epithelial damage & $200(98 \%)$ & $21(100 \%)$ & $15(100 \%)$ & $60(100 \%)$ \\
\hline lymphoid follicles & $27(13 \%)$ & $12(57 \%)$ & $14(93 \%)$ & $8(13 \%)$ \\
\hline glandular atrophy & $25(12 \%)$ & $2(10 \%)$ & $1(7 \%)$ & $9(15 \%)$ \\
\hline intestinal metaplasia & $18(9 \%)$ & $0(0 \%)$ & $0(0 \%)$ & $3(5 \%)$ \\
\hline H. pylori density & $91(45 \%)$ & $12(57 \%)$ & $14(93 \%)$ & $9(0 \%)$ \\
\hline
\end{tabular}


Table VIII. Summary of intercorrelation among various histological parameters with each other

\begin{tabular}{|c|c|c|c|c|c|c|c|}
\hline PARAMETERS & $\begin{array}{c}\text { CHRONIC } \\
\text { INFILTRATE }\end{array}$ & ACTIVITY & H.PYLORI & $\begin{array}{c}\text { GLANDULAR } \\
\text { ATROPHY }\end{array}$ & $\begin{array}{c}\text { SURFACE } \\
\text { EPITHELIAL } \\
\text { DAMAGE }\end{array}$ & $\begin{array}{l}\text { INTESTINAL } \\
\text { METAPLASIA }\end{array}$ & $\begin{array}{c}\text { LYMPHOID } \\
\text { FOLLICLES }\end{array}$ \\
\hline chronic infiltrate & - & $\mathrm{p}=0.00$ & $\mathrm{p}=0.00$ & $\mathrm{p}=0.12$ & $\mathrm{p}=0.01$ & $\mathrm{p}=0.15$ & $\mathrm{p}=0.00$ \\
\hline activity & $\mathrm{p}=0.00$ & - & $\mathrm{p}=0.00$ & $\mathrm{p}=0.58$ & $\mathrm{p}=0.02$ & $\mathrm{p}=0.99$ & $\mathrm{p}=0.00$ \\
\hline H. pylori & $\mathrm{p}=0.00$ & $\mathrm{p}=0.00$ & - & $\mathrm{p}=0.53$ & $\mathrm{p}=0.01$ & $p=0.09$ & $\mathrm{p}=0.00$ \\
\hline glandular atrophy & $\mathrm{p}=0.10$ & $\mathrm{p}=0.58$ & $\mathrm{p}=0.53$ & - & $\mathrm{p}=0.19$ & $\mathrm{p}=0.00$ & $\mathrm{p}=0.30$ \\
\hline $\begin{array}{l}\text { surface epithelial } \\
\text { damage }\end{array}$ & $\mathrm{p}=0.01$ & $\mathrm{p}=0.02$ & $\mathrm{p}=0.01$ & $\mathrm{p}=0.19$ & - & $\mathrm{p}=0.13$ & $\mathrm{p}=0.00$ \\
\hline $\begin{array}{l}\text { intestinal } \\
\text { metaplasia }\end{array}$ & $\mathrm{p}=0.15$ & $\mathrm{p}=0.99$ & $\mathrm{p}=0.09$ & $\mathrm{p}=0.13$ & $p=0.13$ & - & $\mathrm{p}=0.10$ \\
\hline lymphoid follicles & $\mathrm{p}=0.00$ & $\mathrm{p}=0.00$ & $\mathrm{p}=0.00$ & $\mathrm{p}=0.30$ & $\mathrm{p}=0.10$ & $\mathrm{p}=0.10$ & - \\
\hline
\end{tabular}

The association between the histological parameters was assesses by means of chi square test. A probability value of $p$ value $=0.05$ was considered statistically significant. * P value equal or less than 0.05 is statistically significant

$* P$ value equal 0.00 is highly significant

*P value greater than 0.05 is not statistically significant

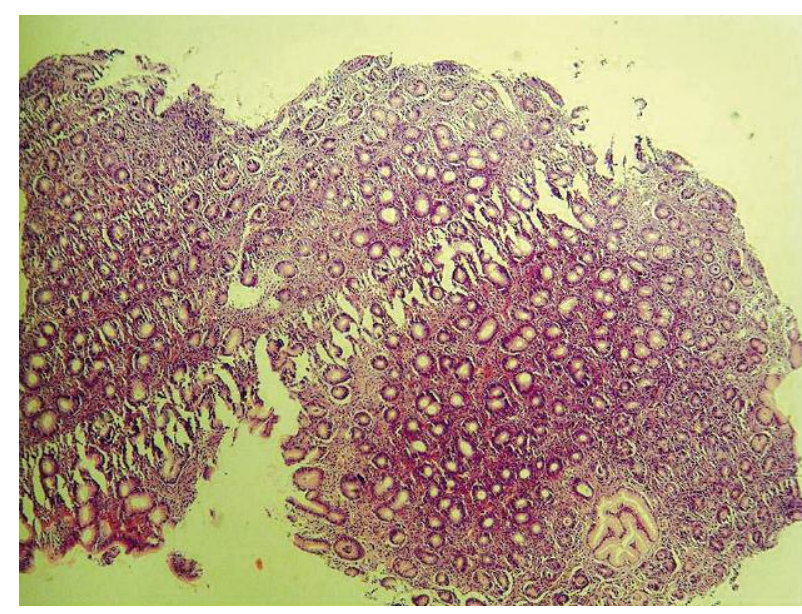

Fig. 1. Gastric biopsy showing surface epithelial erosion. Magnification $40 \times$

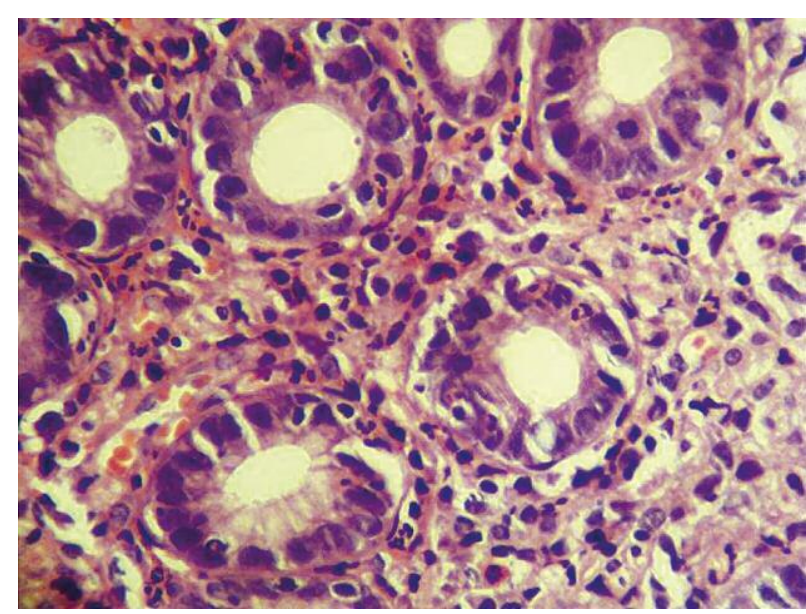

Fig. 3. Gastric biopsy showing intraepithelial neutrophils. Magnification $400 \times$

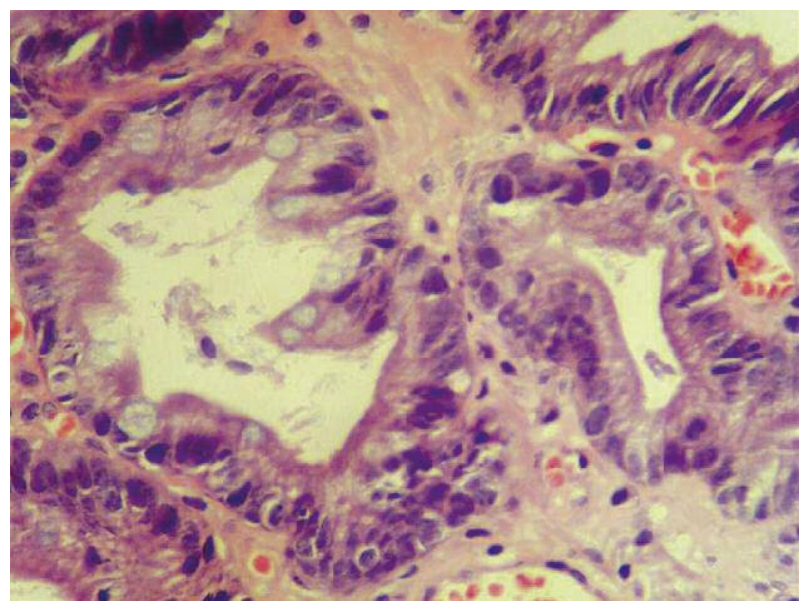

Fig. 2. Gastric biopsy showing intestinal metaplasia. Magnification $400 \times$

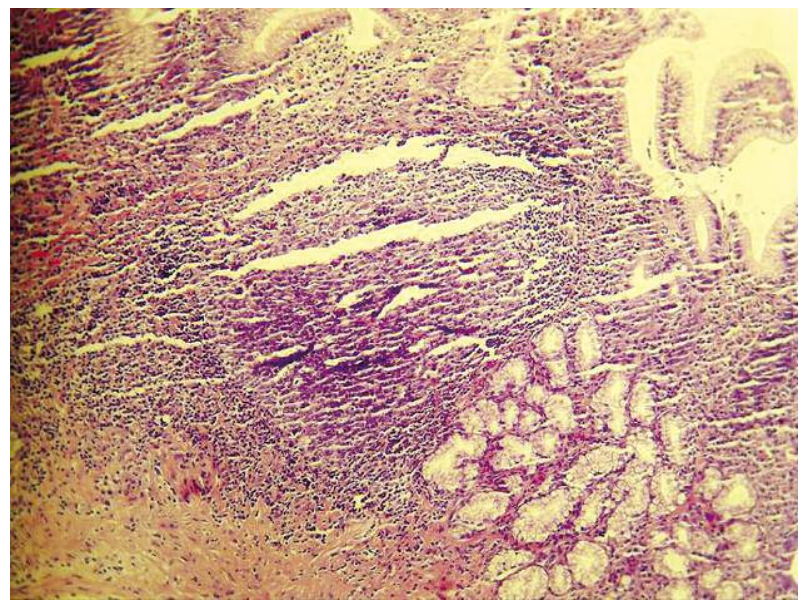

Fig. 4. Gastric biopsy showing lymphoid follicle. Magnification $100 \times$ 
inflammatory activity of $H$. pylori, surface epithelial damage and lymphoid follicles.

E. Correlation of surface epithelial damage and other parameters

Chronic infiltrates, activity, $H$. pylori density and lymphoid follicles had a strong correlation with surface epithelial damage, while a glandular atrophy and intestinal metaplasia had no association.

F. Correlation of intestinal metaplasia with other parameters

Only glandular atrophy was associated with intestinal metaplasia. Other parameters were not statistically significant.

G. Correlation of lymphoid follicles with other parameters

There was a statistically significant association between lymphoid follicles and chronic infiltrate, activity, $H$. pylori and surface epithelial damage; whereas glandular atrophy and intestinal metaplasia had no association with lymphoid follicles.

\section{Discussion}

In the present analysis, the most common age group affected by chronic gastritis was 46-60 years with a mean age of 47 years, which is consistent with studies done by Aydin et al. [3] and Mustapha et al. [6] who reported a mean age of 47.2 years. A higher incidence was seen in males with an $\mathrm{M}: \mathrm{F}$ ratio of $2.1: 1$. Chen et al. [7] also found a $\mathrm{M}: \mathrm{F}$ ratio of $1.8: 1$.

In this study we concentrated only on antral biopsies because most of the studies have reported that antrum is the most likely site of histopathological findings in gastritis [8]. The criteria laid down by Aydin et al. [3] are extremely useful in analyzing the gastric biopsies for suspected gastritis.

The endoscopic findings in our study revealed the presence of erythema in $68 \%$ of cases, antral erosion in $7 \%$, duodenal ulcer in $5 \%$ and normal gastric mucosa in $20 \%$ of cases. These findings were also noted by Khakoo et al. [9] and Calabrese et al. [10] who found erythema in $44 \%$ and $43 \%$ of cases, respectively. Chronic inflammatory infiltrate was found in the majority of the cases (70\%). However, in $20 \%$ of cases who were endoscopically normal, chronic inflammation was also revealed on histology; which was also observed by Khan et al. [11] who had $32 \%$ of patients with chronic gastritis histologically and normal endoscopic findings, hence emphasizing the role of biopsy even in normal endoscopic cases. Frequency of $H$. pylori in the present study in patients with hyperema and erosion was $37 \%$ and $57 \%$, respectively. In patients with duodenal ulcer, colonization by $H$. pylori was seen in 93\% of cases; which is extremely significant. Also the majority of patients with duodenal ulcer had more severe gastritis on histology as compared to subjects having antral hyperemia and erosions. Chronic in-

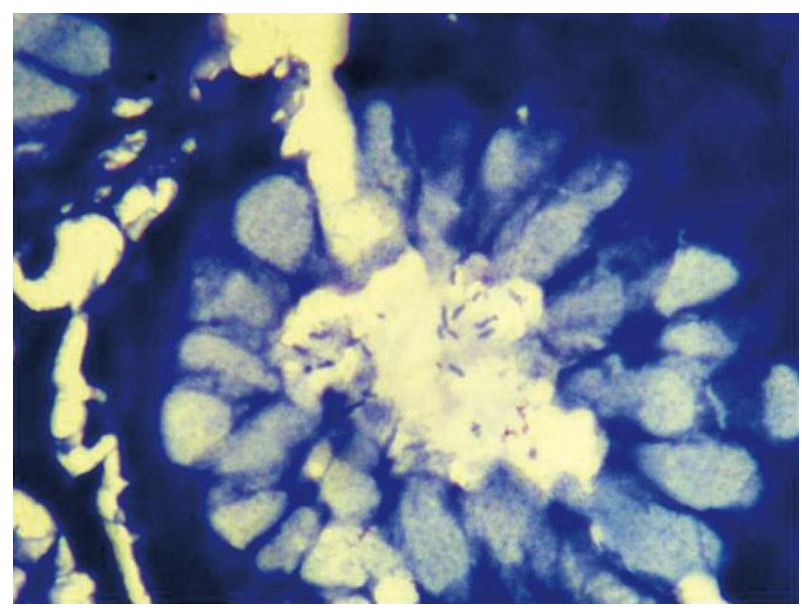

Fig. 5. Gastric biopsy showing H. pylori. Magnification $1000 \times$

flammatory infiltrates were present in all the cases with the majority $(70 \%)$ having only mild inflammation while $27 \%$ had moderate inflammation. A study done by Witteman et al. [12] observed chronic infiltrate in all biopsies but the majority had moderate inflammation. In $33 \%$ of our cases, an activity was seen, which is in accordance with a study published by Misra et al. [13]. Also in cases with a significant activity, $H$. pylori density was very high. Glandular atrophy was seen in only $12.33 \%$ of cases and intestinal metaplasia again in only $7 \%$ of cases. This was also observed by Atisook et al. [14] and Nawfal et al. [15]. Helicobacter pylori was observed in $43 \%$ of all the cases only in our study while studies done by Kumar et al. [16] and Gill et al. [17] showed positivity in $78 \%$ and $65 \%$ of cases, respectively. This low prevalence of $H$. pylori could be attributed to the use of proton pump inhibitors by the patients and also some patients were on antibiotics which are known to suppress $H$. pylori.

In $98.67 \%$ of antral biopsies, we observed surface epithelial damage. Lymphoid aggregates and lymphoid follicles were identified in $25 \%$ and $19 \%$ of subjects, respectively. Two cases were reported as low grade $B$ cell lymphoma of the MALT type. The paradox that lymphoid follicles are absent in normal stomach mucosa is explained by the observation that mucosa-associated lymphoid tissue (MALT) appears in stomach in response to $H$. pylori infection. Hyperactive follicles may then develop into lymphoma. The presence of lymphoid follicles was strongly associated with severe mucosal inflammation, activity and $H$. pylori infection.

We observed that chronic inflammatory infiltrate correlated strongly with acute inflammatory activity, surface epithelial damage, lymphoid follicle and density of $H$. pylori. There was no correlation between chronic inflammation and intestinal metaplasia and glandular atrophy. This was also seen by Witteman et al. [12]. 
Again presence of neutrophils meant a higher density of $H$. pylori, chronic inflammatory infiltrate, more surface epithelial damage and lymphoid follicles. Khalid et al. [19] also reported that neutrophil activity is very commonly noted in $H$. pylori infection. A greater density of organisms was noted in higher grades of inflammation, surface epithelial damage and lymphoid follicles. Mysorekar et al. [18] also substantiated this finding. However, in our study there was no association among $H$. pylori, intestinal metaplasia and glandular atrophy. In fact, intestinal metaplasia is considered a negative indicator for $H$. pylori colonization; meaning that $H$. pylori does not colonize epithelium that has undergone intestinal metaplasia. This was also seen by Witteman et al. [12]. Lymphoid follicles also correlated strongly with mucosal inflammation activity, epithelial damage and density of $H$. pylori. It is widely believed that presence of lymphoid follicles and aggregates in gastric mucosa is a conspicuous feature of $H$. pylori-associated chronic gastritis as lymphoid tissue hyperplasia is a specific immunological reaction to $H$. pylori infection. Studies have shown that a proliferation of $\mathrm{T}$ cells and macrophages is induced by $H$. pylori, which release several cytokines (interleukin 2 and 6) which leads to proliferation of B cells and development of lymphoid follicles.

In conclusion, our study has highlighted the role of histopathology in all cases of gastritis and shown that H. pylori is strongly associated with an acute and chronic inflammatory infiltrate. Hence, we suggest that a search for $H$. pylori should be initiated if neutrophils and lymphoid follicles are seen in the antral biopsies. Also the modified Sydney classification is extremely useful in analyzing antral biopsies. It was also observed that cases of duodenal ulcer had much severer antral gastritis and stronger positivity for $H$. pylori. Intestinal metaplasia and glandular atrophy is not correlated with other histological parameters and $H$. pylori infection. Meanwhile, histological features like lymphoid follicles, activity, H. pylori density and surface epithelial damage are associated with one another.

\section{References}

1. Misiewicz JJ, Iytgat GN, Goodman CS, et al. The Sydney System: a new classification of gastritis. J Gastroenterol Hepatol 1991; 6: 209-212.

2. Dixon MF, Genta RM, Yardley JH, Correa P. Classification and grading of gastritis. The updated Sydney System. International Workshop on the Histopathology of Gastritis, Houston 1994. Am J Surg Pathol 1996; 20: 1161-1181.

3. Aydin O, Egilmez R, Karabacak T, Kanik A. Interobserver variation in histopathological assessment of Helicobacter pylori gastritis. World J Gastroenterol 2003; 9: 2232-2235.

4. Wotherspoon AC, Doglioni C, Diss TC, et al. Regression of primary low-grade B-cell gastric lymphoma of mucosa-associated lymphoid tissue type after eradication of Helicobacter pylori. Lancet 1993; 342: 575-577.

5. Armitage P, Berry G. Statistical methods in medical research Blackwell Scientific Publications, Oxford 1987.
6. Mustapha SK, Bolori MT, et al. Endoscopic findings and the frequency of Helicobacter pylori among dyspeptic patients in NorthEastern Nigeria. Internet J Gastroenterology 2007; 6: 1528-1532.

7. Chen XY, Liu WZ, Shi Y, et al. Helicobacter pylori associated gastric tissue and lymphoid tissue hyperplasia in gastric antral mucosa. J Clin Pathol 2002; 55: 133-137.

8. Eriksson NK, Färkkilä MA, Voutilainen ME, Arkkila PE. The clinical value of taking routine biopsies from the incisura angularis during gastroscopy. Endoscopy 2005; 37: 532-536.

9. Khakoo SI, Lobo AJ, Shepherd NA, Wilkinson SP. Histological assessment of the Sydney classification of endoscopic gastritis. Gut 1994; 35: 1172-1175.

10. Calabrese C, Di Febo G, Brandi G, et al. Correlation between endoscopic features of gastric antrum, histology and Helicobacter pylori infection in adults. Ital J Gastroenterol Hepatol 1999; 31: 359-365

11. Khan MQ, Alhomsi Z, Al-Momen S, Ahmad M. Endoscopic features of Helicobacter pylori induced gastritis. Saudi J Gastroenterol 1999; 5: 9-14.

12. Witteman EM, Mravunac M, Becx MJ, et al. Improvement of gastric inflammation and resolution of epithelial damage one year after eradication of Helicobacter pylori. J Clin Pathol 1995; 48: $250-256$.

13. Misra V, Misra SP, Dwivedi M, Singh PA. Point prevalence of peptic ulcer and gastric histology in healthy Indians with Helicobacter pylori infection. Am J Gastroenterol 1997; 92: 1487-1491.

14. Atisook K, Kachinthorn U, Luengrojanakul P. Histology of gastritis and Helicobacter pylori infection in Thailand: a nationwide study of 3776 cases. Helicobacter 2003; 8: 132-141.

15. Hussein NR, Napaki SM, Atherton JC. A study of Helicobacter pylori-associated gastritis patterns in Iraq and their association with strain virulence. Saudi J Gastroenterol 2009; 15: 125127.

16. Kumar A, Bansal R, Pathak VP, et al. Histopathological changes in gastric mucosa colonized by $\mathrm{H}$. pylori. Indian J Pathol Microbiol 2006; 49: 352-356.

17. Gill HH, Desai HG, Majmudar P, et al. Epidemiology of Helicobacter pylori: the Indian scenario. Indian J Gastroenterol 1993; 12: 9-11.

18. Mysorekar VY, Chitralekha, Dandekar P, Prakash BS. Histopathological changes in acid peptic disease associated with Helicobacter pylori. Indian J Pathol Microbiol 1992; 23: 548556.

19. Alam K, Schubert TT, Bologna SD, Ma CK. Increased density of Helicobacter pylori on antral biopsy is associated withseverity of acute and chronic inflammation and likelihood of duodenal ulceration. Am J Gastroenterol 1992; 87: 424-428.

\section{Address for correspondence}

Bhavna Garg MD

Dayanand Medical College \& Hospital

Ludhiana, India

e-mail: dr.bhavnagarg@yahoo.in 